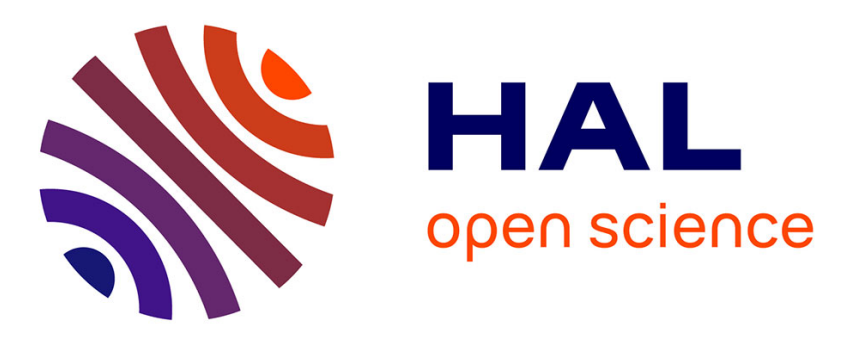

\title{
Influence of surface and subsurface Co-Ir alloy on the electronic properties of graphene
}

Kangli Wang, Thomas Vincent, Jean Baptiste Bouhiron, Stephane Pons, Dimitri Roditchev, Sabina Simon, Mikhail Fonin, Beate Paulus, Yuriy

Dedkov, Sergio Vlaic, et al.

\section{To cite this version:}

Kangli Wang, Thomas Vincent, Jean Baptiste Bouhiron, Stephane Pons, Dimitri Roditchev, et al.. Influence of surface and subsurface Co-Ir alloy on the electronic properties of graphene. Carbon, 2021, 183, pp.251-258. 10.1016/j.carbon.2021.06.082 . hal-03365369

\section{HAL Id: hal-03365369 \\ https://hal.science/hal-03365369}

Submitted on 5 Oct 2021

HAL is a multi-disciplinary open access archive for the deposit and dissemination of scientific research documents, whether they are published or not. The documents may come from teaching and research institutions in France or abroad, or from public or private research centers.
L'archive ouverte pluridisciplinaire HAL, est destinée au dépôt et à la diffusion de documents scientifiques de niveau recherche, publiés ou non, émanant des établissements d'enseignement et de recherche français ou étrangers, des laboratoires publics ou privés. 


\section{Graphical Abstract}

Influence of surface and subsurface Co-Ir alloy on the electronic properties of graphene

Kangli Wang, Thomas Vincent, Jean Baptiste Bouhiron, Stephane Pons,

Dimitri Roditchev, Sabina Simon, Mikhail Fonin, Beate Paulus, Yuriy Dedkov, Sergio Vlaic, Elena Voloshina

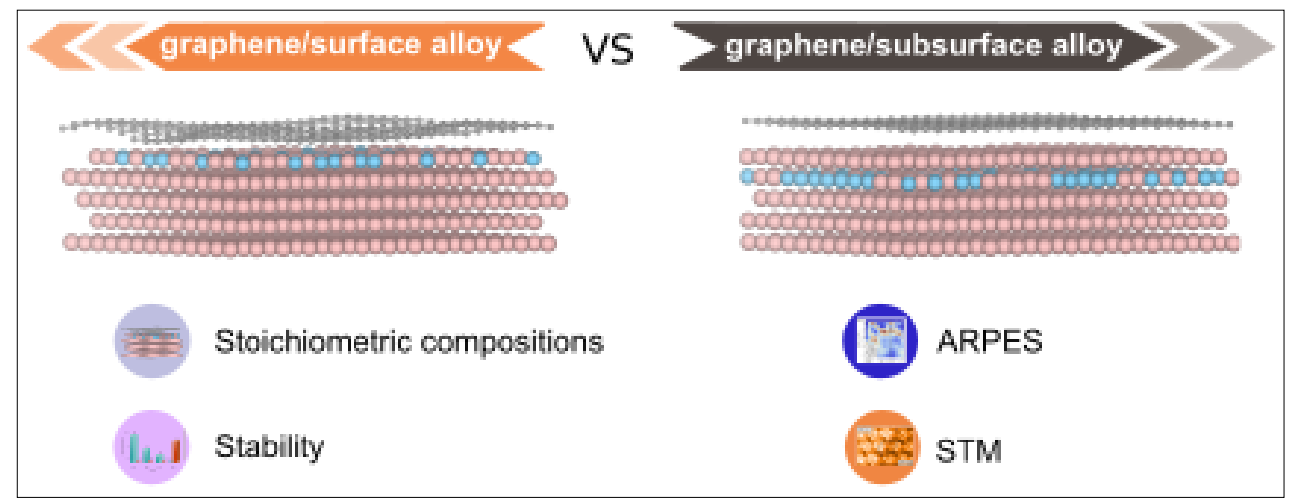




\section{Highlights}

Influence of surface and subsurface Co-Ir alloy on the electronic properties of graphene

Kangli Wang, Thomas Vincent, Jean Baptiste Bouhiron, Stephane Pons,

Dimitri Roditchev, Sabina Simon, Mikhail Fonin, Beate Paulus, Yuriy Dedkov, Sergio Vlaic, Elena Voloshina

- The composition and position of CoIr alloy affects the graphene layer morphology

- The presence of Co at the interface tends to destroy the Dirac cone

- The Dirac cone is preserved if subsurface Co-Ir alloy is formed 


\section{Influence of surface and subsurface Co-Ir alloy on the electronic properties of graphene}

Kangli Wang ${ }^{\mathrm{a}}$, Thomas Vincent ${ }^{\mathrm{b}}$, Jean Baptiste Bouhiron ${ }^{\mathrm{b}, \mathrm{c}}$, Stephane Pons $^{\mathrm{b}}$, Dimitri Roditchev ${ }^{\mathrm{b}}$, Sabina Simon ${ }^{\mathrm{d}}$, Mikhail Fonin ${ }^{\mathrm{d}}$, Beate Paulus ${ }^{\mathrm{a}}$, Yuriy Dedkov ${ }^{\mathrm{a}, \mathrm{e}, *}$, Sergio Vlaic ${ }^{\mathrm{b}, * *}$, Elena Voloshina ${ }^{\mathrm{a}, \mathrm{e}}$

${ }^{a}$ Institut für Chemie und Biochemie, Freie Universität Berlin, Arnimallee 22, 14195 Berlin, Germany

${ }^{b}$ Laboratoire de Physique et dÉtude des Matériaux, ESPCI Paris, PSL Research University, CNRS, UMR 8213, Sorbonne Universités, UPMC Univ. Paris 06, 75005 Paris, France

${ }^{c}$ Laboratoire Kastler Brossel, Collége de France, CNRS, ENS-PSL University, Sorbonne Universités, 11 Place Marcelin Berthelot, 75005 Paris, France

${ }^{d}$ Department of Physics, University of Konstanz, 78457 Konstanz, Germany ${ }^{e}$ Department of Physics, Shanghai University, Shangda Road 99, 200444 Shanghai, China

\section{Abstract}

Using density functional theory (DFT) calculations and angle-resolved photoemission spectroscopy (ARPES) the structural and electronic properties of graphene on the surface and subsurface Co-Ir alloy are investigated upon the intercalation of Co in graphene/Ir(111). It is found computationally that the interaction strength between graphene and substrate is strongly affected by the composition and nature of an alloy, implying the large difference in the electronic structure of monolayer graphene on $\mathrm{Co}_{x} \operatorname{Ir}_{1-x} / \operatorname{Ir}(111)$ and $\operatorname{Ir} / \mathrm{Co}_{x} \operatorname{Ir}_{1-x} / \operatorname{Ir}(111)$. All theoretical results are supported by our ARPES

\footnotetext{
${ }^{*}$ Corresponding author

** Corresponding author

Corresponding author

Email addresses: yuriy.dedkov@icloud.com (Yuriy Dedkov), sergio.vlaic@espci.fr (Sergio Vlaic), elena.voloshina@icloud.com (Elena Voloshina)
} 
data, which demonstrate the disappearance of the Dirac cone when graphene lies on Co and its restoration upon the formation of the subsurface Co-Ir alloy.

Keywords:

graphene, intercalation, alloy, DFT, LEED, STM, ARPES

\section{Introduction}

Since the first isolation of free-standing graphene (gr) and remarkable experiments on its transport properties in 2005 [1, 2], numerous studies have been conducted on graphene mainly due to its excellent electronic [3], ther-

5 mal [4], and mechanical [5] properties. However, the low production output of the mechanical exfoliation method (which is usually used in the studies of transport properties of graphene) and its low scalability make it unavailable for the large scale production of graphene. Therefore, many approaches for synthesising graphene have been developed, such as epitaxial growth on $\mathrm{SiC}$ surfaces [6, 7, 8], reduction of graphene oxide [9, 10], and chemical vapor deposition (CVD) on metals and semiconductors [11, 12, 13, 14]. Among these strategies, the CVD of graphene on metals has become the most promising approach because of its inexpensive and large-scale preparation of highquality graphene films [15, 16. Moreover, it is found that the graphene-metal system is a very interesting object in itself [17, 18, 19, 20]. For example, the moiré structure is formed by graphene on a variety of metal substrates, such as $\operatorname{Ir}(111)[21,22,23,24,25,26]$ and $\operatorname{Ru}(0001)$ [27, 28, 29, 30, 31] due to the relatively large lattice constant mismatch between graphene and substrate. More interestingly, the ferromagnetic substrates, such as $\mathrm{Co}(0001)$ 
and $\mathrm{Ni}(111)$, induce magnetic polarisation in graphene and overlap with a graphene valence state in reciprocal space for one spin direction only [32, 33, 34, 35, 36], which are appealing properties for future spintronic devices [37]. Intercalation of different species, and particularly metal layers, in between graphene and substrate offers an effective route towards modifying the structural, electronic, and magnetic properties of graphene. For example, the single layer of $\mathrm{Cu}$ sandwiched between graphene and $\operatorname{Ir}(111)$ opens a band gap in the graphene $\pi$ bands resulted from the hybridisation between the $\mathrm{Cu}$ and the carbon derived states [38]. Moreover, the implementation of magnetic ultra-thin films into the graphene-metal system, like gr/Co/Ir(111), allows achieving a remarkable enhancement of perpendicular magnetic anisotropy (PMA) via the interaction between graphene and the underlying magnetic metal thick film [39, 40, 41]. However, the intercalation of alloy in between graphene and substrate, which may bring new properties to graphene, is still largely unexplored [42, 43].

In this combined theoretical and experimental study, we gain a unique and detailed insight into the properties of graphene on surface alloy gr $/ \mathrm{Co}_{x} \operatorname{Ir}_{1-x} / \operatorname{Ir}(111)$ and subsurface alloy gr $/ \operatorname{Ir} / \mathrm{Co}_{x} \operatorname{Ir}_{1-x} / \operatorname{Ir}(111)$. By performing the state-of-the-art first principles calculations, we explore how different compositions of surface and subsurface Co-Ir alloy influence the moiré structure, graphene-metal charge transfer, band structure, and stability of a graphene layer on $\operatorname{Ir}(111)$, and further compare them with the experimental results. The deeper insights into the interplay between graphene structure and different kinds of Co-Ir alloy from this study are expected to provide a useful guide for achieving precise layer controlled graphene growth and the 
design of graphene-based devices.

\section{Computational and Experimental Details}

DFT calculations. The DFT calculations were carried out with the Vienna ab initio simulation package (VASP) [44, 45, 46, employing the generalised gradient approximation (GGA) functional of Perdew, Burke and Ernzerhof (PBE) [47]. The van der Waals interactions were incorporated by the semi-empirical approach of Grimme through the D2 correction [48]. The ion-cores were described by projector-augmented-wave (PAW) potentials [49] and the valence electrons [C $(2 s, 2 p)$, Ir $(5 d, 6 s)$, Co $(3 d, 4 s)]$ were described by plane waves associated to kinetic energies of up to $500 \mathrm{eV}$. A $\Gamma$-centred $3 \times 3 \times 1 \mathrm{k}$-point mesh was used. Due to the different lattice constants of graphene and metal support, the systems studied in the present work were modelled by a $(10 \times 10)$ graphene unit cell placed on a $(9 \times 9)$ cell of $\operatorname{Ir}(111)$ with the intercalation of Co-Ir alloy. The Co-Ir alloy is simulated by a $\mathrm{Co}_{x} \operatorname{Ir}_{1-x}$ layer after random replacing Ir atoms by Co atoms. In order to prevent interlayer interaction within the periodic images, a vacuum spacing of $20 \AA$ was applied for all systems. Our slab geometry includes in total 605 atoms (1 layer of graphene, 1 layer of $\mathrm{Co}_{x} \operatorname{Ir}_{1-x}$ alloy and 4 layers of Ir) in the unit cell. The lattice constant in the lateral plane was set according to the optimised value of bulk metal $\left(a_{\operatorname{Ir}(111)}=2.723 \AA\right)$. The positions $(x$, $y, z$ coordinates) of $\mathrm{C}$ atoms and intercalant as well as $z$-coordinates of the two topmost layers of the substrate were fully relaxed until the forces were smaller than $0.02 \mathrm{eV} / \AA$. The convergence criteria for energy was set equal to $10^{-5} \mathrm{eV}$. The STM images were calculated using the Tersoff-Hamann formal- 
ism [50]. To recover an effective primitive cell band structure picture from $(h \nu=40.8 \mathrm{eV})$ as a photon source. During ARPES measurements the sample was placed on the 6-axis fully motorised manipulator and was kept at 
$T<50 \mathrm{~K}$. STM experiments were carried with an Omicron VT STM in the

constant-current mode at room temperature using electrochemically etched polycrystalline tungsten tips cleaned in UHV by flash annealing. The sign of the bias voltage corresponds to the voltage at the sample. Tunnelling parameters are: $U_{T}=1 \mathrm{~V}$ for tunnelling voltage and $I_{T}=1 \mathrm{nA}$ for tunnelling current.

\section{Results and Discussion}

\subsection{Theoretical analysis}

To understand how the different stoichiometric compositions of $\mathrm{Co}_{x} \operatorname{Ir}_{1-x}$ alloy influence the morphological structure of the gr/Co-Ir interface, five values for the ratio $x=0.00,0.25,0.50,0.75,1.00$ are considered with a random distribution of the Co atoms in the alloy. Moreover, surface and subsurface alloys: $\mathrm{Co}_{x} \operatorname{Ir}_{1-x}, \mathrm{Co}_{x} \operatorname{Ir}_{1-x} / \mathrm{Co}_{x} \operatorname{Ir}_{1-x}$ and $\operatorname{Ir} / \mathrm{Co}_{x} \operatorname{Ir}_{1-x}$ on $\operatorname{Ir}(111)$ substrate are used to absorb the graphene layer. The summary of theoretical results for all studied systems are presented in Table S1 of Supporting Information. Here we only focus on the gr $/ \mathrm{Co}_{x} \operatorname{Ir}_{1-x} / \operatorname{Ir}(111)$ and gr $/ \operatorname{Ir} / \mathrm{Co}_{x} \operatorname{Ir}_{1-x} / \operatorname{Ir}(111)$ systems. The corresponding structures obtained after full relaxation of atomic positions are displayed in Figure 1 .

In considerations of graphene on close-packed metal surfaces, several high symmetry positions are usually identified: ATOP, FCC, and HPC (Fig. 11(a)), which are surrounded by a carbon ring with respect to the adsorption position [19]. From Figure 1(b)-(e) and TableS1 of Supporting Information it can be clearly seen that an enhanced corrugation of the graphene moiré superstructure is formed on the top of $\mathrm{Co}_{x} \operatorname{Ir}_{1-x} / \operatorname{Ir}(111)$ compared to that on 
$\operatorname{Ir}(111)$. For $x=0.25$, the minimum distance between graphene and the first layer of the substrate is $3.017 \AA$, indicating the physisorption of graphene on the substrate. As $x$ increases, the average height of the graphene layer with respect to the first layer dramatically decreases. At the same time for large $x$, we observe the coexistence of physisorbed and chemisorbed graphene, depending on the lateral position of $\mathrm{C}$ atoms above the top layer of the substrate. The physisorbed regime dominated by the van der Waals interaction 125 is mainly distributed around the ATOP site with $\Delta h>3.0 \AA$, resulting in the formation of local protrusions. In the chemisorbed case, a close adsorption distance reaches a value as low as $\approx 1.9 \AA(1.883 \AA$ for $x=0.50,1.895 \AA$ for $x=0.75$ and $1.912 \AA$ for $x=1.00$ ), since the $p_{z}$ orbitals of $\mathrm{C}$ atoms hybridise strongly with the Co $d$ orbitals. Therefore, the graphene corrugation becomes pronounced with the increase of $x$.

In contrast, the presence of subsurface alloy of $\operatorname{Ir} / \mathrm{Co}_{x} \operatorname{Ir}_{1-x}$ weakens the corrugation of the graphene layer compared to the $\mathrm{gr} / \operatorname{Ir}(111)$ system as shown in Figure 1(f)-(i) and TableS1 of Supporting Information. In particular, the local protrusions around ATOP tend to be flat, leading to an indistinct moiré structure. For all cases of the $\mathrm{gr} / \mathrm{Ir} / \mathrm{Co}_{x} \operatorname{Ir}{ }_{1-x} / \operatorname{Ir}(111)$ interface, the calculated distances between graphene and the first metal layer keep around $3.4 \AA$ and are characteristic of physisorbed graphene, which indicates that the interaction of graphene with Ir layer is rather weak. With the increase of $x$, there is no obvious change in the corrugation, suggesting the insensitivity of morphological structure to the subsurface alloy. Overall, on the basis of structural arguments, our calculations reveal that the position, as well as stoichiometric compositions of the Co-Ir alloy, drives the corrugation of the 
graphene layer in the mismatched structures.

The interfacial charge density differences for $\operatorname{gr} / \mathrm{Co}_{x} \operatorname{Ir}_{1-x} / \operatorname{Ir}(111)$ and

145 substrate (Fig. 2(a)), implying the big difference in the electronic structure 
of monolayer graphene on $\mathrm{Co}_{x} \operatorname{Ir}_{1-x} / \operatorname{Ir}(111)$ and $\operatorname{Ir} / \mathrm{Co}_{x} \operatorname{Ir}_{1-x} / \operatorname{Ir}(111)$.

In order to assess the stability of the considered systems, we compare the

170 obtain the energy difference $(\Delta E)$ per atom as a function of $x$ ratio as illustrated in Figure 2(b). At $x=0.25$, the gr $/ \operatorname{Ir} / \mathrm{Co}_{x} \operatorname{Ir}_{1-x} / \operatorname{Ir}(111)$ is energetically more favourable than gr $/ \mathrm{Co}_{x} \operatorname{Ir}_{1-x} / \operatorname{Ir}(111)$ by $9.4 \mathrm{meV}$ per atom, despite the interaction between graphene and the first layer in $\operatorname{gr} / \operatorname{Ir} / \mathrm{Co}_{x} \operatorname{Ir}_{1-x} / \operatorname{Ir}(111)$ 175 is much weaker than that in $\mathrm{gr} / \mathrm{Co}_{x} \mathrm{Ir}_{1-x} / \operatorname{Ir}(111)$. As the $x$ value increases, the $\mathrm{gr} / \mathrm{Ir} / \mathrm{Co}_{x} \operatorname{Ir}_{1-x} / \operatorname{Ir}(111)$ is consistently more stable, but the total energy difference per atom significantly decreases: $\Delta E=4.3 \mathrm{meV}$ for $x=0.50$ and $\Delta E=2.2 \mathrm{meV}$ for $x=0.75$. However, when the $x$ increases to 1 , the energy difference has an opposite trend, where the gr $/ \operatorname{Ir} / \mathrm{Co}_{x} \operatorname{Ir}_{1-x} / \operatorname{Ir}(111)$ this phenomenon mainly to the following joint effects: (1) the interaction between the top layer of the substrate and the graphene layer and (2) the deformation energy of graphene. More specifically, at a low Co concentration, the interaction between the graphene layer and the surface Co-Ir alloy ing a subsurface alloy underneath the gr/Ir interface bilayer. With the increases of $x$, more chemical bonds are constructed between graphene and Co-Ir alloy in system of gr $/ \mathrm{Co}_{x} \operatorname{Ir}_{1-x} / \operatorname{Ir}(111)$, thereby stabilising its system and further reducing the energy difference between $\operatorname{gr} / \mathrm{Co}_{x} \operatorname{Ir}_{1-x} / \operatorname{Ir}(111)$ and $\operatorname{gr} / \operatorname{Ir} / \mathrm{Co}_{x} \operatorname{Ir}_{1-x} / \operatorname{Ir}(111)$. When the $x$ reaches a certain value, the interaction between graphene and surface alloy is strong enough to overcome the deformation of a graphene monolayer and therefore the alloy tends to exist on the 
surface under graphene. Our structure and stability analysis also confirms that the selective tuning of the Co concentration enables modifying the moiré tion, new $\pi$ and $\sigma$ states appear accompanied by the original one. As the 
$x$ value becomes 1 , the band structure of $\mathrm{gr} / \mathrm{Co} / \operatorname{Ir}(111)$ is similar to that of $\mathrm{gr} / \mathrm{Co}_{0.5} \operatorname{Ir}_{0.5} / \operatorname{Ir}(111)$ with one exception that the band structure evolves clearly and the $\pi$ and $\sigma$ states exhibit a clear shift toward more negative energy (Fig. S2(d)).

When graphene is adsorbed on $\operatorname{Ir} / \mathrm{Co}_{x} \operatorname{Ir}_{1-x} / \operatorname{Ir}(111)$, the dispersion of the graphene-derived $\pi$ state in the vicinity of the $\mathrm{K}$ point and Dirac cone can still be clearly identified for $x=0.5$ and $x=1$ (Fig. 3(c) and (d)). In the case of complete Co monolayer (i. e. $x=1$ ), a clear $p$-doping of a graphene layer is detected with the calculated position of the Dirac point of $E_{D}-E_{F}=0.27 \mathrm{eV}$ and $E_{D}-E_{F}=0.18 \mathrm{eV}$ for spin-up and spin-down channels, respectively. Furthermore, one can observe the existence of the energy gap of $0.20 \mathrm{eV}$ in the energy dispersion of the $\pi$-band (Fig. $3(\mathrm{c}$ )). For $x=0.5$, graphene derived $\pi$-bands are slightly blurred, that does not allow to determine clearly neither position of Dirac point nor the band gap width (Fig. 3(d)). Still, quasi freestanding character of a $p$-doped graphene is undoubted. We also note that even though a complete monolayer of Co is present at the subsurface, the graphene $\pi$ band at he $\mathrm{K}$ point is weakly spin-polarised with $0.09 \mathrm{eV}$ energy splitting (Fig. 3(d)).

\subsection{Experimental results}

The experimental verification of the theoretical predictions reported in this work requires an excellent control of the Co-Ir alloy formation below the graphene layer. Since the graphene growth requires high temperatures (typically above $1000 \mathrm{~K}$ [56, 19]), at which a previously absorbed Co thin film will desorb from the metallic substrate, the experimental realisation of the proposed systems has been achieved by intercalation technique of Co be- 
tween graphene and $\operatorname{Ir}(111)$ substrate. In such systems Co can intercalates by thermal annealing both through the defects in the graphene layer and nisms can be controlled by the sample preparation conditions [57, 58]. It has been demonstrated that the intermixing between Co and Ir atoms starts at temperatures of above $773 \mathrm{~K}[59,60]$. To control the onset of the alloy formation, we therefore fixed the Co intercalation temperature to $673 \mathrm{~K}$, i. e. below the intermixing temperature, and the alloying has been achieved by a further annealing to $873 \mathrm{~K}$. Due to the reduced mobility of Co atoms under graphene [61], the graphene layer has been grown by temperature programmed growth (TPG) [21] ensuring the presence of a high density of nanometric holes necessary to perform the intercalation from the side of the graphene flake. Figure S3 (a) and (b) in Supporting Information demonstrate the efficiency of this procedure and the absence of Co-Ir alloying upon intercalation. The graphene layer becomes strongly corrugated (corrugation of about $0.1 \mathrm{~nm}$ ) as expected for the Co intercalated graphene (see Fig. S3 of Supporting Information for the STM simulations and Refs. 40, 61. The presence of nanometric holes in the graphene layer results only in a broadening of its bands dispersions observed in the photoemission data by a factor of $\approx 1.5$ [22], which, within our resolution, is equivalent to the one of a complete graphene layer grown by standards CVD technique [53] as shown in Figure S3(c)-(f) of Supporting Information. These properties makes our sample preparation method ideal for the present study.

In order to identify the electronic dispersion originating from the intercalated Co layer and its effect on the graphene dispersion, we first present the 
electronic properties of the bare $\operatorname{Ir}(111)$ substrate along the $\mathrm{M}_{\mathrm{gr}}-\mathrm{K}_{\mathrm{gr}}-\Gamma$ direction (see Fig. 4(a,b)). Here, three Ir-derived surface states, named $S 1, S 2$ and $S 3$, are easily recognisable. Another electronic band, named $I$ according to refs [62, 63], is weekly dispersing. At the $\mathrm{K}_{\mathrm{gr}}$ point the $S 2$ and $S 3$ states become barely distinguishable, while the $I$ state moves to higher binding energy. The effect of the $1 \mathrm{ML}$ deposition of Co at room temperature on bare $\operatorname{Ir}(111)$ is showed in Figure 4(c). Co grows pseudomorphic to Ir, as seen by the LEED diffraction pattern shown as inset, modifying the electronic dispersion. Along the $\mathrm{K}_{\mathrm{gr}}-\Gamma$ direction a new state, dispersing similarly to the $I$ state, appears at a lower binding energy $(\approx 100 \mathrm{meV})$. Along the $\mathrm{M}_{\mathrm{gr}}-\mathrm{K}_{\mathrm{gr}}$ direction, this new states mimics the dispersion of the $S 3$ state. From these data, it is possible to conclude that Co electrons hybridize with the $\operatorname{Ir}(111)$ surface states and the $I$ state leading to the new Co1 state making it a clear indicator of the structural quality of the Co-Ir interface.

Figure 4(d) shows the effect of $1 \mathrm{ML}$ Co intercalation between graphene (covering $75 \%$ of the surface as shown in Supplemental Informations) and $\operatorname{Ir}(111)$. Here the Co has been deposited at $673 \mathrm{~K}$ assuring intercalation but avoiding any alloy with the Ir substrate. In agreement with our theoretical calculations, the graphene Dirac cone vanishes from the Fermi level while the Co1 state can be easily detected. The LEED pattern, shown as inset, demonstrates the presence of graphene through the typical moiré diffraction pattern of graphene on metals with high lattice mismatch.

According to our calculations, the subsurface Co-Ir alloy is energetically favorable at low Co concentration. To test the effect of such configuration on the electronic properties of the system we first intercalated 0.5 ML of Co 
between graphene (75\% coverage) and $\operatorname{Ir}(111)$ by Co deposition at $673 \mathrm{~K}$. The electronic dispersion of such sample is shown in Figure 4(e). The Co1 state and the graphene Dirac cone can be easily identified. Moreover the graphene Dirac cone can be fitted by a tight binding model up to the third nearest neighbour (red dashed lines). The excellent agreement, as expected for quasi-freestanding graphene [64], of the fit demonstrates that our sample is composed of regions of $\mathrm{gr} / \operatorname{Ir}(111)$ and regions of $\mathrm{gr} / \mathrm{Co} / \operatorname{Ir}(111)$. A further annealing to $873 \mathrm{~K}$ dramatically changes the electronic dispersion (Fig. 4(f)) via the formation of the Co-Ir alloy. Along the $\mathrm{M}_{\mathrm{gr}}-\mathrm{K}_{\mathrm{gr}}$ direction the dispersion of the Co1 state is clearly modified. Moreover the Dirac cone, although still present at the Fermi level, shrinks and its dispersion changes with respect the tight binding model. The strong enhancement of all the band width is probably due to the formation of Co-Ir alloy with a random stoichiometry but the presence of the graphene Dirac cone suggest the formation of a subsurface alloy according to our calculations.

\section{Conclusions}

In summary, we systematically studied the interaction and electronic properties of a graphene layer with $\mathrm{Co}_{x} \operatorname{Ir}_{1-x} / \operatorname{Ir}(111)$ and $\operatorname{Ir} / \mathrm{Co}_{x} \operatorname{Ir}_{1-x} / \operatorname{Ir}(111)$ with variable Co concentration by DFT-D2 method. The computational results indicate that the surface alloy of $\mathrm{Co}_{x} \operatorname{Ir}_{1-x}$ on $\operatorname{Ir}(111)$ will remarkably enhance the corrugation of the graphene moiré superstructure, and this trend strengthens with the increase of $x$. In contrast, the subsurface alloy of $\mathrm{Co}_{x} \operatorname{Ir}_{1-x}$ in $\operatorname{Ir}(111)$ would suppress the geometrical corrugation and this effect is rather insensitive to the $x$ value, leading to a relatively flat graphene mono- 
layer. Accordingly, there is more charge accumulation between graphene and surface alloy, especially at the chemisorption region of $\operatorname{gr} / \mathrm{Co}_{x} \operatorname{Ir}_{1-x} / \operatorname{Ir}(111)$; the presence of the subsurface alloy slightly weakens the charge transfer between graphene and Ir surface layer due to the electronic structure effect. The analysis of stability suggests that at low Co concentration, the $\mathrm{Co}_{x} \operatorname{Ir}_{1-x}$ alloy prefers to exist on the subsurface underneath the gr/Ir interface bilayer to interact indirectly with the graphene layer; whereas at high Co concentration, $\mathrm{Co}_{x} \mathrm{Ir}_{1-x}$ alloy tends to segregate to the surface, thereby directly bonding with the graphene monolayer. This depends on the balance between the deformation of graphene and the interaction of graphene with the substrate. Our band structure calculation shows that the strong interaction of graphene with Co atoms destroys the Dirac cone; the formation of a subsurface Co-Ir alloy weakens the interaction between graphene and substrate and thereby makes the graphene layer more quasi freestanding with weak $p$ doping. The results of our DFT calculations are supported by intensive ARPES measurements, which demonstrate that, when graphene is lying on a Co monolayer on $\operatorname{Ir}(111)$, the Dirac cone vanishes. The formation of subsurface Co-Ir alloy restores the presence of the Dirac cone at the Fermi level.

\section{Acknowledgements}

K. W. acknowledges the China Scholarship Council for the financial support. The computations were performed with resources provided by the North-German Supercomputing Alliance (HLRN) and computer facilities of the Freie Universität Berlin (ZEDAT). 


\section{References}

[1] K. S. Novoselov, A. K. Geim, S. V. Morozov, D. Jiang, M. I. Katsnelson, I. V. Grigorieva, S. V. Dubonos, A. A. Firsov, Two-dimensional gas of massless Dirac fermions in graphene, Nature 438 (7065) (2005) 197-200.

[2] Y. Zhang, Y.-W. Tan, H. L. Stormer, P. Kim, Experimental observation of the quantum Hall effect and Berry's phase in graphene, Nature 438 (7065) (2005) 201-204.

[3] P. Pokharel, Q.-T. Truong, D. S. Lee, Multi-step microwave reduction of graphite oxide and its use in the formation of electrically conductive graphene/epoxy composites, Compos. B. Eng. 64 (C) (2014) 187-193.

[4] A. A. Balandin, S. Ghosh, W. Bao, I. Calizo, D. Teweldebrhan, F. Miao, C. N. Lau, Superior thermal conductivity of single-layer graphene, Nano Lett. 8 (3) (2008) 902-907.

[5] C. Lee, X. Wei, J. W. Kysar, J. Hone, Measurement of the elastic properties and intrinsic strength of monolayer graphene, Science 321 (2008) $385-388$.

[6] C. Berger, Z. Song, X. Li, X. Wu, N. Brown, C. Naud, D. Mayou, T. Li, J. Hass, A. N. Marchenkov, E. H. Conrad, P. N. First, W. A. de Heer, Electronic Confinement and Coherence in Patterned Epitaxial Graphene, Science 312 (5777) (2006) 1191-1196.

[7] C. Berger, Z. Song, T. Li, X. Li, A. O. T. J. of, 2004, Ultrathin epitaxial graphite: 2D electron gas properties and a route toward graphene-based nanoelectronics, J. Phys. Chem. B 108 (2004) 19912-19916. 
[8] K. V. Emtsev, A. Bostwick, K. Horn, J. Jobst, G. L. Kellogg, L. Ley, J. L. McChesney, T. Ohta, S. A. Reshanov, J. Röhrl, E. Rotenberg, A. K. Schmid, D. Waldmann, H. B. Weber, T. Seyller, Towards wafersize graphene layers by atmospheric pressure graphitization of silicon carbide, Nat. Mater. 8 (2009) 203-207.

[9] D. R. Dreyer, S. Park, C. W. Bielawski, R. S. Ruoff, The chemistry of graphene oxide, Chemical Society Reviews 39 (1) (2009) 228-240.

[10] Y. Hernandez, V. Nicolosi, M. Lotya, F. M. Blighe, Z. Sun, S. De, I. T. McGovern, B. Holland, M. Byrne, Y. K. Gun'Ko, J. J. Boland, P. Niraj, G. Duesberg, S. Krishnamurthy, R. Goodhue, J. Hutchison, V. Scardaci, A. C. Ferrari, J. N. Coleman, High-yield production of graphene by liquid-phase exfoliation of graphite, Nature Nanotechnol. 3 (9) (2008) $563-568$.

[11] Q. Yu, J. Lian, S. Siriponglert, H. Li, Y. P. Chen, S.-S. Pei, Graphene segregated on Ni surfaces and transferred to insulators, Appl. Phys. Lett. 93 (11) (2008) 113103.

[12] X. Li, W. Cai, J. An, S. Kim, J. Nah, D. Yang, R. Piner, A. Velamakanni, I. Jung, E. Tutuc, S. K. Banerjee, L. Colombo, R. S. Ruoff, Large-area synthesis of high-quality and uniform graphene films on copper foils, Science 324 (2009) 1312-1314.

[13] J.-H. Lee, E. K. Lee, W.-J. Joo, Y. Jang, B.-S. Kim, J. Y. Lim, S.H. Choi, S. J. Ahn, J. R. Ahn, M.-H. Park, C.-W. Yang, B. L. Choi, S.-W. Hwang, D. Whang, Wafer-scale growth of single-crystal mono- 
layer graphene on reusable hydrogen-terminated germanium, Science 344 (6181) (2014) 286-289.

[14] Y. S. Dedkov, E. Voloshina, Epitaxial graphene/Ge interfaces: a minireview, Nanoscale 12 (21) (2020) 11416-11426.

[15] S. Bae, H. Kim, Y. Lee, X. Xu, J.-S. Park, Y. Zheng, J. Balakrishnan, T. Lei, H. R. Kim, Y. Il Song, Y.-J. Kim, K. S. Kim, B. Özyilmaz, J.-H. Ahn, B. H. Hong, S. Iijima, Roll-to-roll production of 30-inch graphene films for transparent electrodes, Nature Nanotechnol. 5 (8) (2010) $574-$ 578.

[16] J. Ryu, Y. Kim, D. Won, N. Kim, J. S. Park, E.-K. Lee, D. Cho, S.-P. Cho, S. J. Kim, G. H. Ryu, H.-A.-S. Shin, Z. Lee, B. H. Hong, S. Cho, Fast Synthesis of High-Performance Graphene Films by Hydrogen-Free Rapid Thermal Chemical Vapor Deposition, ACS Nano 8 (1) (2014) 950-956.

400

[17] M. Batzill, The surface science of graphene: Metal interfaces, CVD synthesis, nanoribbons, chemical modifications, and defects, Surf. Sci. Rep. 67 (3-4) (2012) 83-115.

[18] Y. S. Dedkov, E. Voloshina, M. Fonin, Scanning probe microscopy and spectroscopy of graphene on metals, Phys. Status Solidi B 252 (3) (2015)

405 $451-468$.

[19] Y. S. Dedkov, E. Voloshina, Graphene growth and properties on metal substrates, J. Phys.: Condens. Matter 27 (30) (2015) 303002. 
[20] M. Yang, Y. Liu, T. Fan, D. Zhang, Metal-graphene interfaces in epitaxial and bulk systems: A review, Prog. Mater. Sci. 110 (2020) 100652.

[21] J. Coraux, A. T. N’Diaye, M. Engler, C. Busse, D. Wall, N. Buckanie, F.-J. M. z. Heringdorf, R. van Gastel, B. Poelsema, T. Michely, Growth of graphene on $\operatorname{Ir}(111)$, New J. Phys. 11 (2009) 023006.

[22] M. Kralj, I. Pletikosić, M. Petrović, P. Pervan, M. Milun, A. T. N’Diaye, C. Busse, T. Michely, J. Fujii, I. Vobornik, Graphene on $\operatorname{Ir}(111)$ characterized by angle-resolved photoemission, Phys. Rev. B 84 (7) (2011) 075427.

[23] C. Busse, P. Lazic, R. Djemour, J. Coraux, T. Gerber, N. Atodiresei, V. Caciuc, R. Brako, A. T. N'Diaye, S. Bluegel, J. Zegenhagen, T. Michely, Graphene on $\operatorname{Ir}(111)$ : Physisorption with chemical modulation, Phys. Rev. Lett. 107 (3) (2011).

[24] E. Starodub, A. Bostwick, L. Moreschini, S. Nie, F. E. Gabaly, K. F. McCarty, E. Rotenberg, In-plane orientation effects on the electronic structure, stability, and Raman scattering of monolayer graphene on Ir(111), Phys. Rev. B 83 (12) (2011) 125428.

[25] I. Pletikosić, M. Kralj, M. Milun, P. Pervan, Finding the bare band: Electron coupling to two phonon modes in potassium-doped graphene on Ir(111), Phys. Rev. B 85 (15) (2012) 155447.

[26] E. Voloshina, E. Fertitta, A. Garhofer, F. Mittendorfer, M. Fonin, A. Thissen, Y. S. Dedkov, Electronic structure and imaging contrast of graphene moiré on metals, Sci. Rep. 3 (2013) 1072. 
[27] S. Marchini, S. Günther, J. Wintterlin, Scanning tunneling microscopy of graphene on $\mathrm{Ru}(0001)$, Phys. Rev. B 76 (7) (2007) 075429.

[28] B. Wang, S. Günther, J. Wintterlin, M. L. Bocquet, Periodicity, work function and reactivity of graphene on $\mathrm{Ru}(0001)$ from first principles, New J. Phys. 12 (4) (2010) 043041.

[29] S. J. Altenburg, J. Kröger, B. Wang, M. L. Bocquet, N. Lorente, R. Berndt, Graphene on $\mathrm{Ru}(0001)$ : Contact formation and chemical reactivity on the atomic scale, Phys. Rev. Lett. 105 (23) (2010) 236101.

[30] E. Voloshina, N. Berdunov, Y. S. Dedkov, Restoring a nearly freestanding character of graphene on $\mathrm{Ru}(0001)$ by oxygen intercalation, Sci. Rep. 6 (2016) 20285.

[31] E. Voloshina, Y. S. Dedkov, Atomic force spectroscopy and densityfunctional study of graphene corrugation on $\mathrm{Ru}(0001)$, Phys. Rev. B 93 (2016) 235418.

[32] V. M. Karpan, G. Giovannetti, P. A. Khomyakov, Graphite and graphene as perfect spin filters, Phys. Rev. Lett. 99 (17) (2007) 176602.

[33] Y. S. Dedkov, M. Fonin, Electronic and magnetic properties of the graphene-ferromagnet interface, New J. Phys. 12 (12) (2010) 125004.

[34] E. Voloshina, R. Ovcharenko, A. Shulakov, Y. S. Dedkov, Theoretical description of X-ray absorption spectroscopy of the graphene-metal interfaces, J. Chem. Phys. 138 (15) (2013) 154706. 
[35] D. Marchenko, A. Varykhalov, J. Sánchez-Barriga, O. Rader, C. Carbone, G. Bihlmayer, Highly spin-polarized Dirac fermions at the graphene/Co interface, Phys. Rev. B 91 (23) (2015) 235431.

[36] D. Usachov, A. Fedorov, M. M. Otrokov, A. Chikina, O. Vilkov, A. Petukhov, A. G. Rybkin, Y. M. Koroteev, E. V. Chulkov, V. K. Adamchuk, A. Grüneis, C. Laubschat, D. V. Vyalikh, Observation of single-spin dirac fermions at the graphene/ferromagnet interface, Nano Lett. 15 (4) (2015) 2396-2401.

[37] S. Roche, J. Åkerman, B. Beschoten, J.-C. Charlier, M. Chshiev, S. P. Dash, B. Dlubak, J. Fabian, A. Fert, M. Guimarães, F. Guinea, I. Grigorieva, C. Schönenberger, P. Seneor, C. Stampfer, S. O. Valenzuela, X. Waintal, B. van Wees, Graphene spintronics: the European Flagship perspective, 2D Mater. 2 (3) (2015) 030202.

[38] H. Vita, S. Böttcher, K. Horn, E. Voloshina, Understanding the origin of band gap formation in graphene on metals: graphene on $\mathrm{Cu} / \mathrm{Ir}(111)$, Sci. Rep. 4 (2014) 5704.

[39] N. Rougemaille, A. T. N'Diaye, J. Coraux, C. Vo-Van, O. Fruchart, A. K. Schmid, Perpendicular magnetic anisotropy of cobalt films intercalated under graphene, Appl. Phys. Lett. 101 (14) (2012) 142403.

[40] R. Decker, J. Brede, N. Atodiresei, V. Caciuc, S. Blügel, R. Wiesendanger, Atomic-scale magnetism of cobalt-intercalated graphene, Phys. Rev. B 87 (4) (2013) 041403. 
[41] J. Coraux, A. T. N'Diaye, N. R. T. J. of, 2012, Air-protected epitaxial graphene/ferromagnet hybrids prepared by chemical vapor deposition and intercalation, J. Phys. Chem. Lett. 3 (2012) 2059-2063.

[42] D. Alfè, M. Pozzo, E. Miniussi, S. Günther, P. Lacovig, S. Lizzit, R. Larciprete, B. S. Burgos, T. O. Menteş, A. Locatelli, A. Baraldi, Fine tuning of graphene-metal adhesion by surface alloying, Sci. Rep. 3 (1) (2013) 2430 .

[43] E. Voloshina, B. Paulus, Y. S. Dedkov, Graphene layer morphology as an indicator of the metal alloy formation at the interface, J. Phys. Chem. Lett. 12 (2021) 19-25.

[44] G. Kresse, J. Furthmuller, Efficiency of ab-initio total energy calculations for metals and semiconductors using a plane-wave basis set, Comp. Mater. Sci. 6 (1) (1996) 15-50.

[45] G. Kresse, J. Hafner, Norm-conserving and ultrasoft pseudopotentials for first-row and transition-elements, J. Phys.: Condens. Matter 6 (40) (1994) 8245-8257.

[46] G. Kresse, J. Hafner, Ab initio molecular dynamics for liquid metals, Phys. Rev. B 47 (1) (1993) 558-561.

[47] J. P. Perdew, K. Burke, M. Ernzerhof, Generalized gradient approximation made simple, Phys. Rev. Lett. 77 (18) (1996) 3865-3868.

[48] S. Grimme, Semiempirical GGA-type density functional constructed with a long-range dispersion correction, J. Comput. Chem. 27 (15) (2006) 1787-1799. 
[49] P. E. Blöchl, Projector augmented-wave method, Phys. Rev. B 50 (24) (1994) 17953-17979.

[50] J. Tersoff, D. R. Hamann, Theory of the scanning tunneling microscope, Phys. Rev. B 31 (2) (1985) 805-813.

[51] P. V. C. Medeiros, S. Stafström, J. Björk, Effects of extrinsic and intrinsic perturbations on the electronic structure of graphene: Retaining an effective primitive cell band structure by band unfolding, Phys. Rev. B 89 (4) (2014) 041407.

[52] P. V. C. Medeiros, S. S. Tsirkin, S. Stafström, J. Björk, Unfolding spinor wave functions and expectation values of general operators: Introducing the unfolding-density operator, Phys. Rev. B 91 (4) (2015) 041116(R).

[53] J. Coraux, A. T. N Diaye, C. Busse, T. Michely, Structural coherency of graphene on $\operatorname{Ir}(111)$, Nano Lett. 8 (2) (2008) 565-570.

${ }_{510}$ [54] T. Vincent, E. Voloshina, S. Pons, S. Simon, M. Fonin, K. Wang, B. Paulus, D. Roditchev, Y. S. Dedkov, S. Vlaic, Quantum well states for graphene spin-texture engineering, J. Phys. Chem. Lett. 11 (2020) $1594-1600$.

[55] Y. S. Dedkov, E. Voloshina, Spectroscopic and DFT studies of graphene intercalation systems on metals, J. Electron. Spectrosc. Relat. Phenom. 219 (2017) 77-85.

[56] H. Tetlow, J. P. de Boer, I. J. Ford, D. D. Vvedensky, J. Coraux, L. Kantorovich, Growth of epitaxial graphene: Theory and experiment, Phys. Rep. 542 (3) (2014) 195-295. 
520

[57] S. Vlaic, A. Kimouche, J. Coraux, B. Santos, A. Locatelli, N. Rougemaille, Cobalt intercalation at the graphene/iridium(111) interface: Influence of rotational domains, wrinkles, and atomic steps, Appl. Phys. Lett. 104 (10) (2014) 101602.

[58] S. Vlaic, N. Rougemaille, A. Kimouche, B. S. Burgos, A. Locatelli,

[62] I. Pletikosić, M. Kralj, P. Pervan, R. Brako, J. Coraux, A. T. N’Diaye, C. Busse, T. Michely, Dirac cones and minigaps for graphene on $\operatorname{Ir}(111)$, Phys. Rev. Lett. 102 (5) (2009) 056808. 
[63] I. Pletikosić, M. Kralj, D. Sokcevic, R. Brako, P. Lazić, P. Pervan, Photoemission and density functional theory study of $\operatorname{Ir}(111)$; energy band 545 gap mapping, J. Phys.: Condens. Matter 22 (13) (2010) 135006.

[64] S. Rusponi, M. Papagno, P. Moras, S. Vlaic, M. Etzkorn, P. M. Sheverdyaeva, D. Pacilé, H. Brune, C. Carbone, Highly anisotropic Dirac cones in epitaxial graphene modulated by an island superlattice, Phys. Rev. Lett. 105 (24) (2010) 246803. 
(a) $g r / \operatorname{lr}(111)$

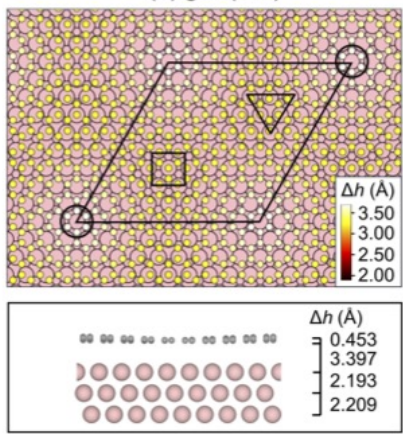

(d) $\mathrm{gr} / \mathrm{Co}_{0.75} \mathrm{Ir} \mathrm{r}_{0.25} / \mathrm{Ir}(111)$
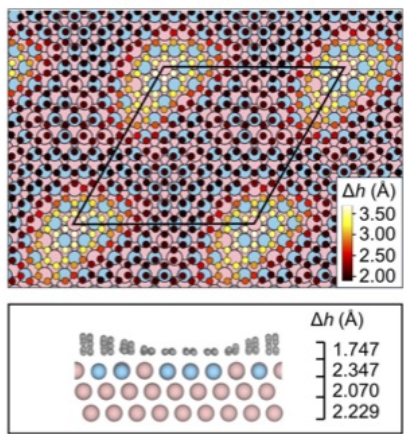

(g) $\mathrm{gr} / \mathrm{lr} / \mathrm{Co}_{0.5} / \mathrm{r}_{0.5} / \mathrm{lr}(111)$
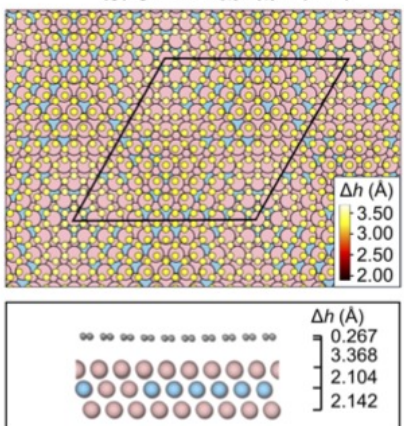

(b) $\mathrm{gr} / \mathrm{Co}_{0.25} / \mathrm{r}_{0.75} / \mathrm{Ir}(111)$

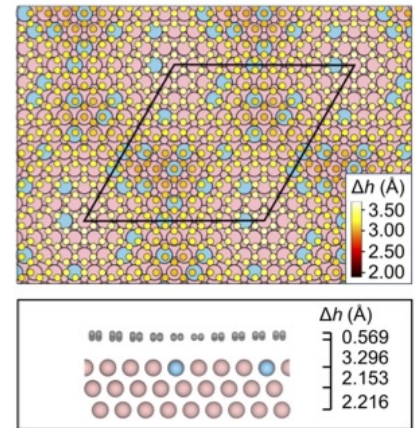

(e) $\mathrm{gr} / \mathrm{Co} / \mathrm{lr}(111)$
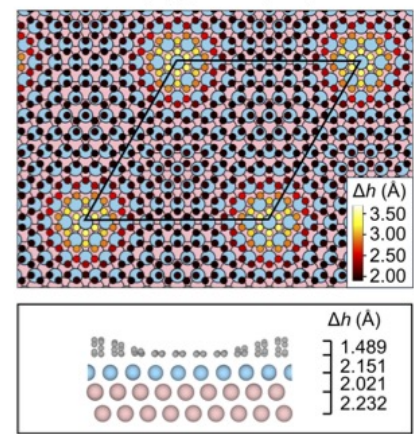

(h) $\mathrm{gr} / \mathrm{Ir} / \mathrm{Co}_{0.75} \mathrm{Ir}_{0.25} / \mathrm{Ir}(111)$

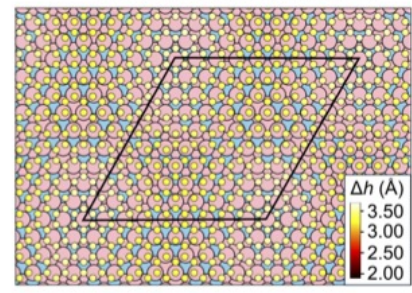

20000000000000000000 $\Delta h(A)$ $200000000000000 \quad-\begin{array}{ll}0.262 \\ 3.435 \\ 2.059\end{array}$ $2000000000-j_{2.101}^{3.435}$ (c) $\mathrm{gr} / \mathrm{Co}_{0.5} \mathrm{Ir} \mathrm{r}_{0.5} / \mathrm{lr}(111)$

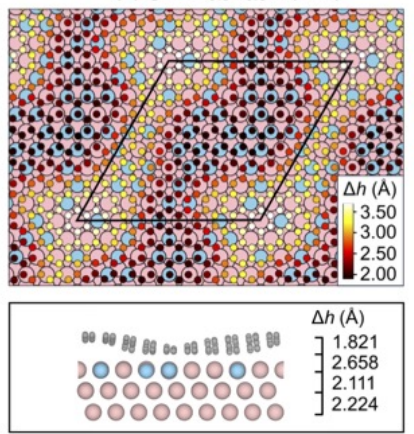

(f) $\mathrm{gr} / \mathrm{lr} / \mathrm{Co}_{0.25} \mathrm{Ir}_{0.75} / \mathrm{Ir}(111)$

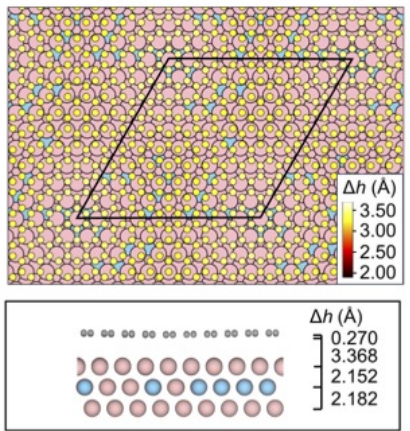

(i) $\mathrm{gr} / \mathrm{lr} / \mathrm{Co} / \mathrm{lr}(111)$

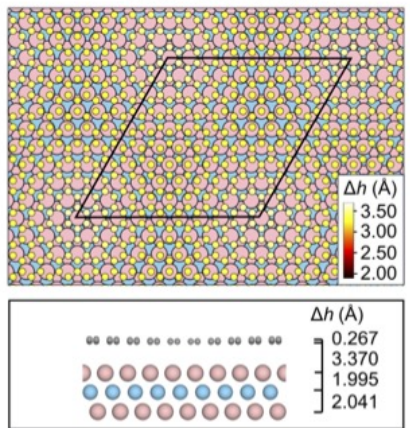

Figure 1: Structural models of (a)-(e) $\mathrm{Gr} / \mathrm{Co}_{x} \operatorname{Ir}_{1-x} / \operatorname{Ir}(111)$ and (f)-(i) $\mathrm{Gr} / \mathrm{Ir} /$ $\mathrm{Co}_{x} \operatorname{Ir}_{1-x} / \operatorname{Ir}(111)$ with $x=0.00,0.25,0.50,0.75$ and 1.00 . The color scale indicates the heights measured from the first layer of the substrate. The black rhombus marks the unit cell of the considered system. Ir and Co atoms are shown in pink and blue, respectively. The high-symmetry places in (a) are marked by circle, square, and triangle for ATOP, FCC, and HCP, respectively. 
(a)

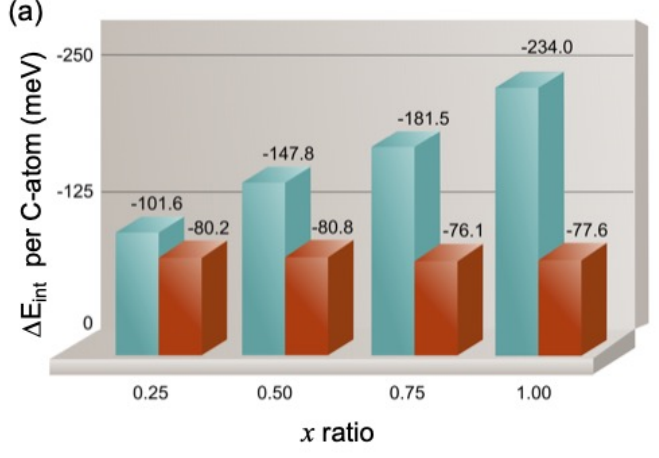

(b)

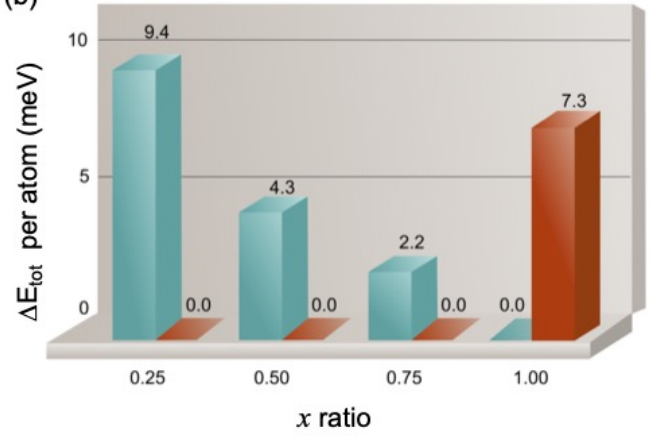

Figure 2: (a) The interaction energy $\left(\Delta E_{\text {int }}\right)$ per C-atom as a function of $x$ ratio for gr $/ \mathrm{Co}_{x} \operatorname{Ir}_{1-x} / \operatorname{Ir}\left(111\right.$ ) (blue) and gr $/ \operatorname{Ir} / \mathrm{Co}_{x} \operatorname{Ir}_{1-x} / \operatorname{Ir}(111)$ (red). (b) The total energy difference $\left(\Delta E_{\text {tot }}\right)$ per atom as a function of $x$ ratio for $\operatorname{gr} / \operatorname{Co}_{x} \operatorname{Ir}_{1-x} / \operatorname{Ir}(111)$ (blue) and $\operatorname{gr} / \operatorname{Ir} / \mathrm{Co}_{x} \operatorname{Ir}_{1-x} / \operatorname{Ir}(111)$ (red). 

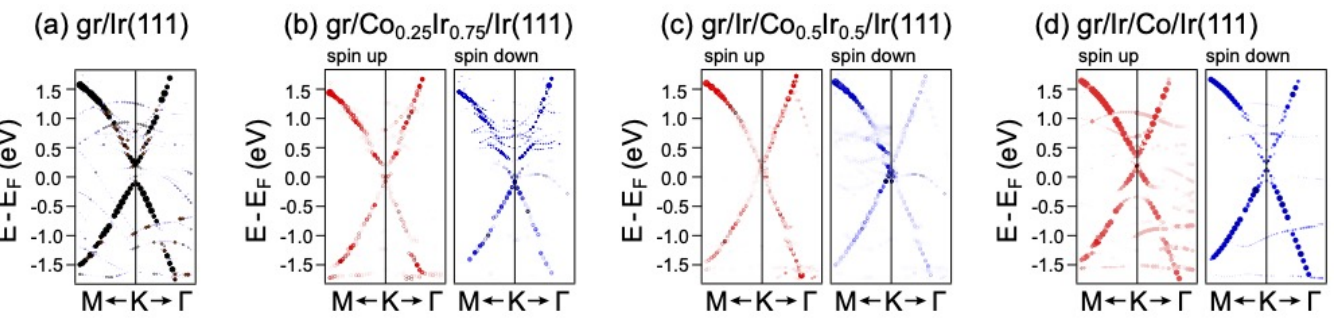

Figure 3: Band structures of (a) gr/Ir(111), (b) $\operatorname{gr} / \mathrm{Co}_{0.25} \operatorname{Ir}_{0.75} / \operatorname{Ir}(111)$, (c) $\mathrm{gr} / \mathrm{Ir} / \mathrm{Co}_{0.5} \mathrm{Ir}_{0.5} / \operatorname{Ir}(111)$ and (d) $\mathrm{gr} / \mathrm{Ir} / \mathrm{Co} / \mathrm{Ir}(111)$ in the vicinity of the $\mathrm{K}$ point obtained after the unfolding procedure for the graphene $(1 \times 1)$ primitive cell. Spin-up (red) and spin-down (blue) states are shown in (b)-(d). 
(a)

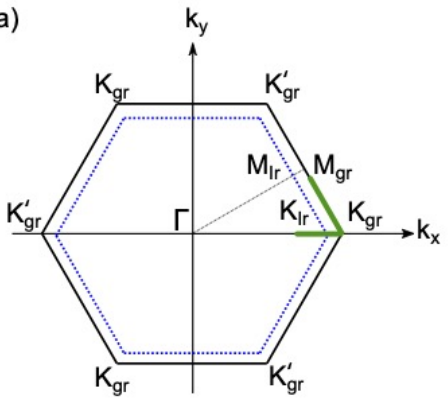

(d)

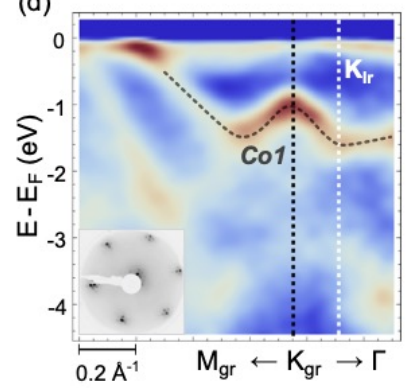

(b)

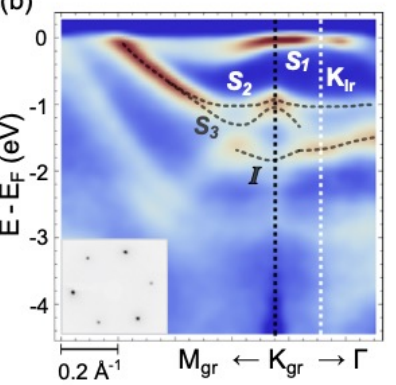

(e)

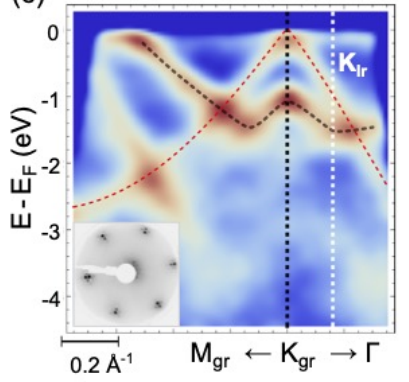

(c)

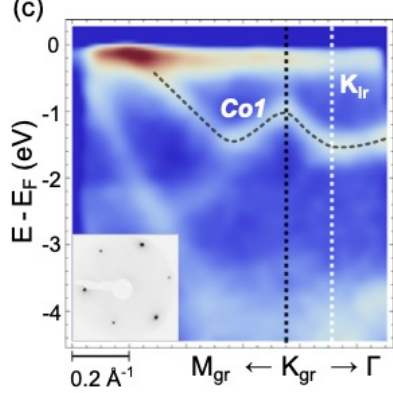

(f)

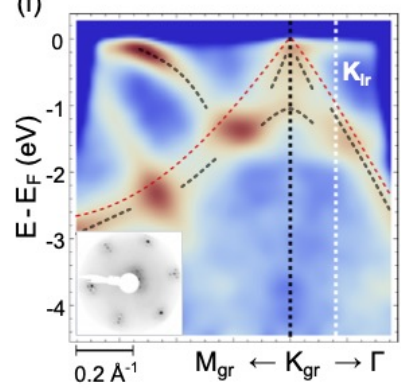

Figure 4: (a) Schematic representation of the gr and $\operatorname{Ir}(111)$ Brillouin zones. The green thick line highlight the $\mathrm{M}_{\mathrm{gr}}-\mathrm{K}_{\mathrm{gr}}-\Gamma$ direction in reciprocal space used for the electronic dispersion shown in (b)-(f). Electronic band dispersions obtained in ARPES experiments for (b) the $\operatorname{Ir}(111)$ surface, (c) single Co layer on $\operatorname{Ir}(111)$, (d) gr/Co $1 \mathrm{ML} / \mathrm{Ir}$, (e) gr $/ \mathrm{Co}_{0.5 \mathrm{ML}} / \mathrm{Ir}(111)$ and (f) gr/Co-Ir alloy obtained by annealing the sample shown in (e) to $873 \mathrm{~K}$. The grey dashed lines highlight the band dispersion in each sample. The red dashed line shows a thigh binding fit up to three nearest neighbour of $\operatorname{gr} / \operatorname{Ir}(111)$. Insets shows the LEED pattern of the corresponding sample. 